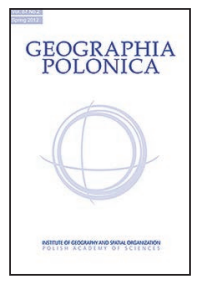

\title{
STUDENTS IN TIMES OF PANDEMIC: EMPLOYMENT, LIVING CONDITIONS, AND HEALTH. CASE STUDIES FROM POLAND, UKRAINE, AND BELARUS
}

\author{
Zofia Kawczyńska-Butrym ${ }^{1}$ (D) - Viktoriya Pantyley ${ }^{2}$ (D) \\ Marek Butrym $^{3}$ (D) - Ganna Kisla ${ }^{4}$ (D) Liudmila Fakeyeva ${ }^{5}$ (D) \\ ${ }^{1}$ Institute of Sociology \\ Maria Curie-Sklodowska University in Lublin \\ Maria Curie-Skłodowska, 4, 20-031 Lublin: Poland \\ e-mail: zofia.kawczynska-butrym@poczta.umcs.lublin.pl \\ ${ }^{2}$ Institute of Socio-Economic Geography and Spatial Management \\ Maria Curie-Sklodowska University in Lublin \\ Kraśnicka, 2 cd, 20-718 Lublin: Poland \\ e-mail: wiktoria.pantylej@poczta.umcs.lublin.pl (corresponding author) \\ ${ }^{3}$ Faculty of Social and Economic Sciences \\ Cardinal Stefan Wyszyński University in Warsaw \\ Wóycickiego, 1/3, building 23, 01-938 Warsaw: Poland \\ e-mail:m.butrym@uksw.edu.pl \\ ${ }^{4}$ Faculty of Socio-Economic Education \\ National Pedagogical Dragomanov University, Kyiv \\ Pyrogova, 9, 01-601 Kyiv: Ukraine \\ e-mail: kisla.ann@gmail.com \\ ${ }^{5}$ Faculty of International Relations \\ Belarusian State University, Minsk \\ Leningradskaya, 20, 220-030 Minsk: Belarus \\ e-mail: fakeyeva@gmail.com
}

\begin{abstract}
The article draws attention to the importance of gainful employment of students. The pandemic has largely limited such opportunities. Study objective: Determination of the scope in which students recognise limitation, its consequences for their plans regarding continuation of university education, life priorities and health self-assessment. The online survey involved the participation of a total of 380 students from Poland, Ukraine, and Belarus. Results: Demonstrated loss of employment, worsening of material situation, declared changes in plans of continuation of university education. Moreover, the respondents assessed their state of health as worse due to the occurrence or intensification of psychosomatic symptoms.
\end{abstract}

\section{Key words}

student • COVID-19 • employment • standard of living • health 


\section{Introduction}

Employment combined with university education is a common feature of higher education in all countries (Hauschildt et al., 2015). Gainful employment of students and its importance and function in student life has only attracted interest in recent years (Godlevska \& Grečaniuk, 2008; Bącik et. al., 2010; Orr et. al., 2011; Zubrzycka, 2015; Marozau \& Apanasovich, 2016; Ostoj, 2016; Parchomiuk \& Zubrzycka-Maciag, 2017; Sokolova 2019). The current state of employment of students is particularly intensively investigated in the scope of the cyclical European research programme EUROSTUDENT beginning from 2000. The programme covers exclusively students from the countries of the European Union as well as Croatia and Turkey (with the exception of EUROSTUDENT $V$ in 20122015 that also included Ukraine and Belarus), and focuses on the comparison of the social and economic situation, sources of financing of university education, and determination of the socioeconomic situation of students. The latest research in the scope of EUROSTUDENT VI shows considerable workload of Polish students (Hauschildt et al., 2018). $89 \%$ of working students devote more than 20 hours per week for gainful employment (EUROSTUDENT VI, 2018: 145). Publication Social and economic conditions of student life in Europe (EUROSTUDENT VI, 2018) emphasises that work during university education entails a risk of discontinuation of education, and constitutes an obstacle for undertaking education abroad (Hauschildt et al., 2018). According to the study, students are most likely to undertake permanent or temporary employment in countries such as Germany, the Czech Republic, or the Netherlands (more than 70\%), and the least likely - in Albania, Italy, and Serbia (below 25\%). Data in the series entitled Combining studies and paid jobs (2018) showed that the percent of students with regular permanent employment during university education from the EHEA region (European Higher Education Area, 28 countries) currently varies from 15\% in Italy, Albania, and Serbia to more than $50 \%$ in Germany and Estonia.

One of the aspects of the analyses of our interest is drawing attention to the scale of undertaking employment by students in the aforementioned countries, and particularly changes in their situation due to the pandemic, as well as drawing attention to changes in the scope of the health condition of students caused by it. It seems that only the pandemic experienced by different countries around the globe permitted drawing greater attention to the importance of gainful employment of students for the economy and students themselves, as well as to changes that occurred in the state of health of students. Our study is of pilot character, and aims at the determination of the occurring directions and tendencies of change in the standard of living and state of health of students caused by the pandemic in Poland, Ukraine and Belarus.

\section{Contexts of the analysis and interpretation of student employment}

The activity of students in the labour market constitutes a form of participation and implementation of one of the priorities designated in the Bologna Strategy. It emphasises the importance of the relationship between the education system and economy for the development and preparation of the young generation for the implementation of the knowledge-based economy. The issue of students in the labour market, however, requires consideration of several contexts:

- although students are recognised as a professionally passive group, they increasingly frequently undertake employment, becoming active participants of the labour market;

- they are particularly active in economic segments showing high demand for parttime, often seasonal work requiring knowledge of foreign languages (in restaurants and gastronomy, commerce, hospitality and tourism, and in various services); 
- gainful employment, according to the data of cyclical research conducted within EUROSTUDENT VI (2018), is undertaken by approximately $51 \%$ of students and has a share of $33 \%$ in the total income structure (next to family support - $46 \%$, scholarships, awards and benefits - 11\%, and other sources, including student loans - 9\%). It significantly affects the general standard of student life, secures payments due in the course of studies, and therefore allows for university education as such. It is therefore understandable that many countries see an increase in the number of students working and studying simultaneously (Orr et al., 2011);

- gainful employment of students also plays an important role in obtaining professional competences, and facilitates entering the labour market after graduation.

The analysis of employment and life strategies of students would not be complete without considering their health condition. It was completely neglected in the cyclical study EUROSTUDENT cited above.

Students should be therefore largely treated as a professionally active group, and their gainful employment should be treated not only as one of the modern styles of student life or increase in human capital, but also as an important source of financing of life and education costs. Such an approach to students' employment adds significance to the question: What changed in the social, life and health situation of students as a result of the pandemic?

\section{Popularisation and motives for undertaking employment by students in Poland, Ukraine, and Belarus}

General data regarding gainful employment of students have been largely unavailable for many years. In Poland, information on the subject has been provided by research conducted at particular universities and on selected majors. Research in the scope of EUROSTUDENT IV (Orr et al., 2011) showed that Polish students devote more time to employment than to studying, second only to their peers from Portugal in terms of time allocated weekly for employment (Lenart, 2014: 125). According to the survey of the Polish Business Roundtable from 2017, almost $80 \%$ of the respondents perform some kind of work, whereas only $41 \%$ are employed based on a contract (SW Research, 2017). According to the survey from December 2019, 82\% of students worked (SW Research, 2019), 20\% among them major in economics or law, $12 \%$ - humanities and arts, while environmental studies, mathematic/statistics, computer science/teleinformation technologies account for $11 \%$ each. All these data point to a growing tendency of undertaking employment by students.

Similar conclusions are drawn by Ukrainian researchers. They assume that the modern labour market creates demand for an employee with incomplete level of qualifications, and student youth in Ukraine meets the requirements of the Ukrainian labour market (Sokolova, 2019). The International Labour Organisation (ILO) in the scope of the Programme for employment of youth, conducted a survey in Ukraine regarding the transition from school to employment (SWTS). The results showed that among all young people, the share of persons that have ever combined studying and working was 30\% (Libanova et al. 2014). Another study in Ukraine showed that $37 \%$ of students worked during their university education (Kogut et al., 2016). A study by A. Sokolova (2019) among students of the East Ukrainian State University of $\mathrm{V}$. Dalia in its regional branches (Luhansk, Severodonieck, and Rubizhne) in 2013 confirmed that the scale of employment of students increased with years spent at the university, with $61 \%$ of students working during the first year, $67.5 \%$ during the second year, and $84.4 \%$ during the third year.

The situation is somewhat different in Belarus, where according to researchers, students' activity in the labour market is low (Lebedevich, 2019: 230-231). Still, in recent years the number of students without employment 
has decreased $(42.26 \%$ in 2009 against $30.3 \%$ in 2016) (Vankevich \& Korabava, 2019: 122). Among working stationary students, $44.3 \%$ are employed long-term, $7.8 \%$ temporarily, and $8.5 \%$ only during summer (Vankevich \& Korabava, 2019: 122). In 2017 the highest number of young people worked in the following sectors: commerce (20.9\%), car repair $(11.4 \%)$, information and communication (11.5\%), art, sports, tourism, and recreation (10.2\%) (Lebedevich, 2019: 232). It is worth emphasising that Belarusian students are more involved in business activity than Polish and Ukrainian students. It is confirmed by results of cyclical sociological survey GUESSS conducted from 2003, analysing, among others, entrepreneurship of students. The 2016 survey showed that $22.9 \%$ of respondents attempted establishing own business activity during their time at the university ( $41 \%$ of male students and $16.4 \%$ of female students). During the time, $7 \%$ of students worked in own companies or were self-employed. This index is somewhat lower than the averaged values for all countries (8.8\% as of 2016), and Belarus ranks the 29th in the world (Marozau \& Apanasovich, 2016: 38). Young people usually organise business activity in such sectors as retail sale, road cargo transport, computer repair, beauty salons and hair styling, construction and carpentry, car repair and technical service, and others (Ignatovitch et al., 2018: 65).

Many Polish authors investigating motives for undertaking gainful employment by students emphasise that the primary one is the financial motive, measured with the amount of work remuneration. The motive of professional development through work experience is mentioned considerably more seldom (Ostoj, 2016; Parchomiuk \& Zubrzycka-Maciag, 2017; PARP, 2019). Ukrainian researchers report the motive of professional development more frequently than Polish ones, but they also take into account conditions permitting combining employment with university education. These include among others flexible employment schedule and non-regulated days and times of work (Kogut et al., 2016). In both countries, a situation co-existing with and justifying undertaking employment is difficult material situation experienced by students (Bacik et al., 2010; Szlendak \& Lemska, 2010; Orr et al., 2011; Portfel studenta, 2019). In Ukraine, low purchasing power of scholarships, necessity of paying for university education, but also willingness to become independent from parents are particularly emphasised (Godlevska \& Grečaniuk, 2008; Kogut et al., 2016; Sokolova, 2019).

In the situation of increasing participation of students in the labour market, and particularly due to difficult financial situation resulting in the necessity of undertaking employment, the question arises: What has changed in the situation of students when the pandemic and the related exclusion of the activity of many segments of the economic life prevented their current functioning in the labour market?

\section{Study objectives and research problems}

The study objective was to determine changes in the situation of students as a result of the pandemic, primarily in the scope of employment, and to determine whether the potential change has affected the self-assessment of the material situation, state of health, and consequently their plans concerning the continuation of university education and life orientation.

The following research problems were stated:

- Did students lose gainful employment during the pandemic and to what degree?

- How do students assess their current material situation in comparison to the situation before the pandemic?

- Did the change in material situation affect their plans concerning university education?

- Does the life being in the pandemic period and potential loss of employment affect their life preferences and health self-assessment? 


\section{Course of the study and study method}

The study was targeted at students at four universities: Marie Curie-Skłodowska University in Lublin (UMCS), National Pedagogical Dragomanov University in Kyiv (UD), Belarusian State University in Minsk (BSU), and Belarusian State University of Informatics and Radioelectronics in Minsk (BSUIR). Due to the ongoing contact restrictions resulting from the pandemic, an online survey was conducted based on an original questionnaire including 19 questions and a scorecard. We asked students to assess their situation before and during the pandemic with regard to the suspension of the university's activity and introduction of on-line learning, and to an assess the potential change in their health condition, life goals, and plans regarding the country of future employment. Because this type of survey lacks representativeness of groups of respondents, and due to the number of completed questionnaires being relatively low (380) and different in respective academic centres, no statistical tests were applied in the analysis, limiting it only to percent analysis. The general characteristics of the respondents are provided in Table 1.

The survey commenced in mid-June, i.e. towards the end of the academic year which due to the pandemic took an online form, and ended in Mid-July, i.e. after the final exams.
The study period did not favour completing surveys due to the end period of online classes, and introduction of a new method of passing classes, taking exams, and defending diploma theses.

\section{Study results}

\section{Loss of employment determining the standard of life during university education}

COVID-19 and the resulting change in the course of university education changed the scope of sources of its financing. The most frequently reported source of financing both before and during the pandemic is family, followed by scholarships, and employment. The percent shares of these categories, however, have changed. A decrease occurred particularly in the case of employment (by 21.6 percent points) and business activity (by $3.3 \mathrm{pp}$ ), i.e. additional sources of income and/or financing university education before the pandemic. The load on family slightly increased (by $2.5 \mathrm{pp}$ ). In the context of the analysed universities, the highest contribution of family in financing students, both before (81.1\%) and during the pandemic $(86.4 \%)$ was observed in the case of students of UD, and lowest - in the case of UMCS (80.5\% and $79.6 \%$, respectively). Bank credits and loans as sources of financing during university education were considerably more

Table 1. General characteristics of respondents in Lublin, Kyiv, and Minsk, $n=380$

\begin{tabular}{|l|c|c|c|}
\hline \multirow{3}{*}{ Variable } & Value of variable & Total number & $\begin{array}{c}\text { Percent share of respondents } \\
{[\%]}\end{array}$ \\
\hline Sex & women & 280 & 73.7 \\
\multirow{4}{*}{ Age } & men & 100 & 26.3 \\
& $17-19$ & 89 & 23.5 \\
\multirow{4}{*}{ Country of origin } & $20-24$ & 280 & 73.7 \\
& $25-26$ & 11 & 2.8 \\
& Poland & 182 & 47.9 \\
University & Ukraine & 133 & 35.0 \\
& Belarus & 65 & 17.1 \\
& UMCS & 221 & 58.2 \\
& UD & 114 & 30.0 \\
\hline
\end{tabular}


frequently reached for by students of UD (more than $60 \%$ of all surveyed students) than by students from the studied Belarusian universities (2.3\%) or students of UMCS (from $2 \%$ before the pandemic to $4 \%$ of respondents during the pandemic). Gainful employment as a source of financing during university education was of the highest importance for the surveyed students of UD, both before and during the pandemic, and lowest - for students from the analysed Belarusian universities (38.6\% before the pandemic and 27.9\% during the pandemic).

In the specific question whether they worked before and during the pandemic, the difference reported by the respondents reached $26.3 \mathrm{pp}$, whereas the highest difference occurred in the case of students from
UD (almost 40\%), and lowest - in the case of the surveyed students from Belarusian universities (approximately 15\%).

The pandemic period resulted in a considerable decrease in students' employment, particularly evident in the service (by $14.7 \mathrm{pp}$ ), gastronomic (9.3 pp), commercial (8.7 pp) and tourism sector (4.2 pp) (Fig. 1).

\section{Assessment of the current material situation of students and their families in comparison to the pre-pandemic situation}

An important change in the life situation resulting from the pandemic is the current standard of living of respondents. The study anticipated that loss of employment would
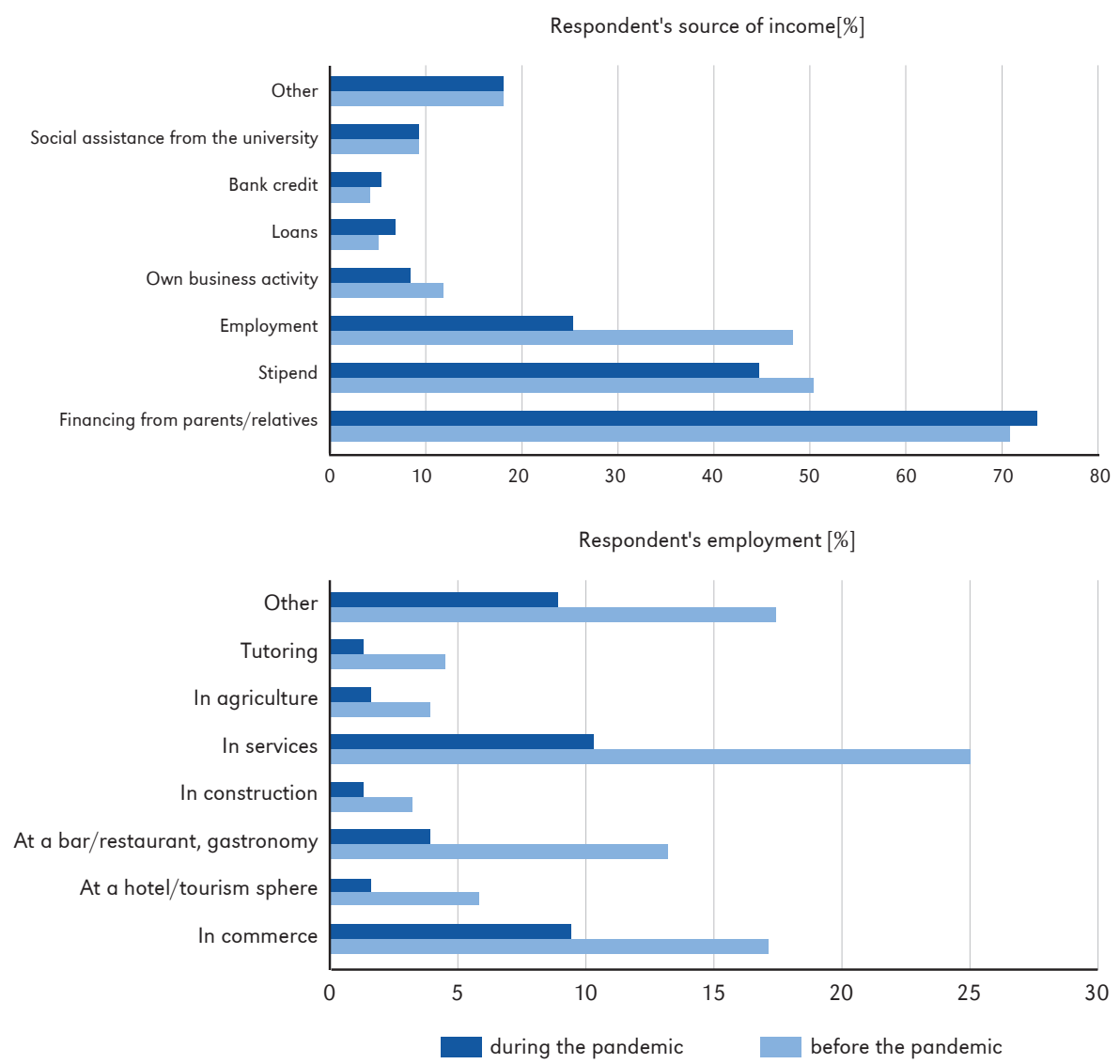

Figure 1. Students' source of income and employment before and during the pandemic, $n=380$ 
induce a change in their self-assessment of material situation. The analysis covered the changes for both students and their families. Taking the family situation into account results from the fact that the family largely secures and finances students during their time at the university. In the study, an average of $40 \%$ of respondents observed no change in their own or their family's situation. Students more frequently reported worsening of their family's situation (in total, considerable and partial worsening was declared by $57.1 \%$ of respondents) than their own situation $(46.6 \%$, respectively). The worst situation concerned families of students from Belarusian universities, and relatively best - families of students from UMCS (Tab. 2).

Improvement of the family's situation (partial and considerable) was reported by a total of only $1.8 \%$ of students (evident dominance of the surveyed students from UMCS), whereas $12.2 \%$ of respondents reported improvement of their own situation (it primarily concerned students from UMCS and the surveyed students from Belarusian universities).

\section{Plans regarding further university situation}

The study included the question whether due to the pandemic, change of studies to the online form, worsening of the employment and material situation, and often return to family home, respondents are planning to change their plans regarding their further education process. According to the survey, the majority of respondents (65.8\%) plan no such changes (no considerable differences were determined between students from universities covered by the sociological research), however, $16.8 \%$ consider temporary, and $4.8 \%$ - permanent discontinuation of university education. In the context of the studied universities, the highest share of students planning to discontinue their university education temporarily or permanently was observed among the surveyed students from UD (21.9\% and 6.1\%, respectively).

Discontinuation or suspension of university education is considered by approximately $22 \%$ of the respondents. More than one in ten (11.3\%) considers a change of major, and part of them declare a change of city of education (10.5\%), or change of university $(6.3 \%)$. Among 45 foreign students from Belarus (21) and Ukraine (24) studying in Poland, only 6 (13.3\%; three from each of the countries) consider dropping out of university.

\section{Health self-assessment of students, and change of life preferences}

One of the trends in research on life satisfaction involves analyses of what determines the meaning of life and sense of happiness in people. For some, the meaning of life means pleasure (hedonists), for others - important, although difficult life goals (eudaimonists). Research shows that the level of satisfaction with life differentiates representatives of both life orientations. Eudaimonists feel happier than hedonists, and 'the hedonist approach in striving for happiness does not favour achieving happiness or better quality

Table 2. Material situation of students and their families, $n=380$

\begin{tabular}{|l|r|r|r|r|r|r|r|r|r|}
\hline \multirow{2}{*}{ Direction of change } & \multicolumn{2}{|c|}{ Student's situation = A } & \multicolumn{2}{|c|}{ Family's situation = B } & \multicolumn{4}{c|}{ B-A } \\
\cline { 2 - 11 } & $\begin{array}{c}\text { BSU and } \\
\text { BSUIR }\end{array}$ & UD & UMCS & $\begin{array}{c}\text { BSU and } \\
\text { BSUIR }\end{array}$ & UD & UMCS & $\begin{array}{c}\text { BSU and } \\
\text { BSUIR }\end{array}$ & UD & UMCS \\
\hline Considerable worsening & 8.9 & 23.9 & 11.4 & 8.9 & 16.7 & 10.0 & 0.0 & +7.2 & +1.4 \\
Partial worsening & 33.3 & 37.6 & 30.0 & 60.0 & 48.2 & 40.7 & -26.7 & -10.6 & -10.7 \\
No change & 46.7 & 29.4 & 44.5 & 31.3 & 33.3 & 41.7 & +15.4 & -3.9 & +2.8 \\
Partial improvement & 11.1 & 7.3 & 13.2 & 0.0 & 0.9 & 1.8 & +11.1 & +6.4 & +11.4 \\
Considerable improvement & 0.0 & 1.8 & 0.9 & 0.0 & 0.9 & 0.5 & 0.0 & +1.3 & +0.4 \\
\hline
\end{tabular}


of life' (Diagnoza Społeczna 2013: 191). It is generally acknowledged that the sense of happiness as well as quality of life and satisfaction with life have a considerable effect on human health. A question remains whether the pandemic contributed to a change in the life orientation, and therefore indirectly affected the state of health of respondents. Before the pandemic (53.9\% of respondents) and during the pandemic (56.6\% of respondents), declarations of students were dominated by orientation to important life goals. In the context of the studied universities, the highest share of students preferring striving towards important life goals to seeking pleasure, both before and during the pandemic, was observed among students from UMCS (almost 60\%), and lowest - among students from Belarusian universities (more than 40\%). A change in life preferences was declared by only 10 persons (difference of $2.7 \mathrm{pp}$ ). This suggests that the pandemic period had no considerable effect on life attitudes of students. A study by P. Długosz (2020a) during the pandemic, however, showed a decrease in the percent share of students satisfied with life from 80 to $74 \%$.

Students were directly asked for a general health self-assessment before and during the pandemic, as well as about ailments and health problems that have appeared or intensified. The pandemic proved to have a very destructive effect on the state of health of students. Respondents assessed the state of their own health as very bad or bad twice more frequently than before the pandemic (currently 6\%) (Fig. 2). The share of students assessing their state of health as good and very good decreased by more than 12 percent points (it is currently only 61.6\%). Meanwhile, comprehensive results of surveys regarding the state of health of people in Poland, conducted by the Central Statistical Office in 2014, showed that the share of persons aged 15-29 assessing the state of their health as 'bad or very bad' was only $1.5 \%$, and 'good and very good' - more than 90\% (Health Status..., 2016).

In the context of the studied universities, the assessment of own health before the pandemic was the most negative in the case of students from UD $(4.4 \%$ of respondents declared that their state of health was bad and very bad), and most positive - for students from UMCS (2.7\%, respectively). At the same time, in the case of students from Belarusian universities, the share of respondents assessing their state of health as good and very good was the highest (75.6\%), whereas the equivalent value among the surveyed students from UD was at a level of $65.0 \%$. The pandemic period considerably changed the distribution of students from different universities: self-assessment of state

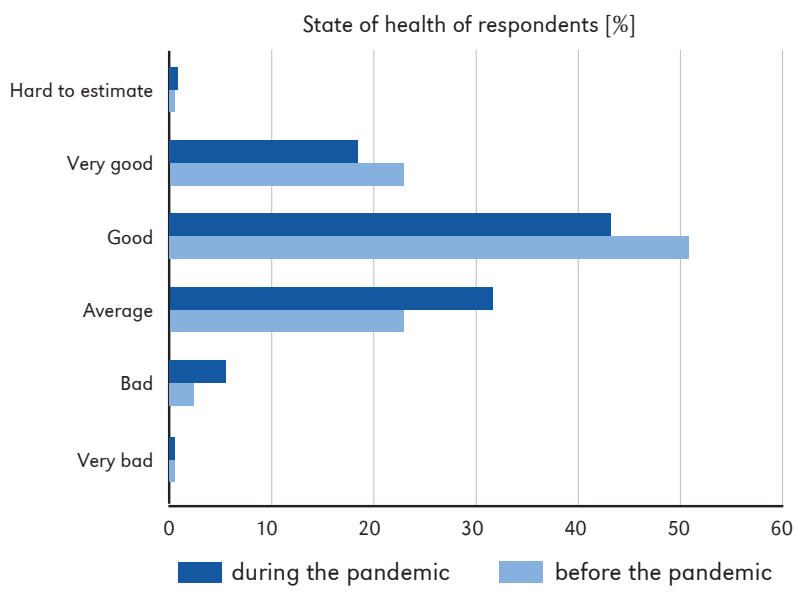

Figure 2. Self-assessment of state of health of respondents, before and during the pandemic, $n=380$ 
of health during the pandemic was the most negative in the case of students from UMCS (9\% of respondents in categories 'bad' and 'very bad' state of health), and most positive for students from UD (approximately $2 \%$ of respondents declared that their state of health is within categories 'bad' or 'very bad'). At the same time, students from UMCS showed the lowest share of respondents assessing their state of health during the pandemic as 'good' and 'very good' (less than $60 \%$ ), whereas the equivalent value among students from UD exceeded $65 \%$.

Among the health issues during the pandemic mentioned in the questionnaire, the respondents most frequently reported the occurrence or intensification of: anxiety (total of $45.3 \%$ of respondents), depression (44.5\%), irritability $(40.5 \%)$, fatigue $(36.6 \%)$, general indisposition (35.2\%), and insomnia (25.2\%). In the context of the studied universities, students from UMCS found themselves in a substantially worse situation according to all the parameters analysed above. Other health issues included the dry eye syndrome, atopic dermatitis, weight gain, limited physical fitness, and breathing issues. Contrary to expectations, young people proved to be the most sensitive age group in terms of effects of the pandemic on the psychological health of the population. This is suggested by research of the Pew Research Centre in the USA that showed that in the age group of 18-29, high and medium stress level was experienced by $61 \%$ of respondents (Pew Research Center, 2020). Research conducted by P. Długosz (2020) in March 2020 on a sample of 3500 students in Kraków, and in June 2020 on a sample of 1927 students, showed considerable worsening of the physical condition of students during the pandemic.

\section{Discussion and conclusions}

Results of this study showed that the greatest change observed during the pandemic in the reduction of sources of income was loss of employment. Jobs were lost by $26.3 \%$ of respondents. Due to lack of employment as well as worsening of the material situation of families financially supporting students during their studies, a total of $46.6 \%$ of students reported worsening of their material situation. This corresponds with survey results for EHEA member states, both in the period before (Hauschildt et al., 2018), and during the pandemic (Student life..., 2020). A survey conducted during the SARS-CoV-2 pandemic among almost 18 thousand respondents in 41 European countries belonging to EHEA showed that financial problems related to financing the costs of university education were experienced by $22.4 \%$ of the surveyed students (Student life..., 2020). The survey also showed that among students working while studying, 28.9\% lost the job temporarily, and $12.2 \%$ permanently. For students for whom working is a necessity to cover the costs of education, this is a risk factor. A survey by P. Długosza (2020b) conducted during the first wave of the pandemic on a sample of 3167 students in Kraków showed that the material situation of students substantially worsened in the case of almost $13.0 \%$ of respondents, and in the case of the remaining ones it did not change (almost 70\% of respondents). A survey conducted in Russia on a sample of 2.7 million Russian students showed that material situation worsened in the case of $14 \%$ of students (Obučenie v period pandemii, 2020). Our study referring to students from selected universities in Poland, Belarus, and Ukraine showed approximate results (almost 15\% of respondents among students from the studied universities in Poland, Ukraine, and Belarus declared considerable worsening of their material situation during the pandemic).

This contributed to the anticipation of potential changes regarding continuation of university education. Although the majority of students do not plan such changes (65.8\%), more than one in five $(21.6 \%)$ consider temporary or permanent discontinuation of university education. It should be emphasised that the trend observed during the pandemic also occurred in the period before the pandemic (as evidenced by surveys by different authors, 
for example Piróg, 2017). According to our research, the plan to leave the university is primarily reported by foreign students. Among 45 foreign students studying in Poland, more than one in seven $(13.3 \%)$ consider dropping out of university. It is a particularly disturbing signal for the global challenge of internationalisation of universities and education processes. The discussed problem is not only the domain of European countries. For example, surveys conducted by Aucejo et al. (2020) among 1500 students at one of the largest public institutions in the U.S. during the SARSCoV-2 pandemic showed that $13 \%$ of students delayed graduation, 40\% lost a job, internship, or offer, and 29\% expected to earn less at the age of 35. Moreover, lower-income students were 55\% more likely than their higher-income peers to have delayed graduation due to coronavirus.

The EUROSTUDENT VI programme neglected the issue of health of students (Hauschildt et al., 2018). Only in 2020, a special issue was published assessing students' life in the EHEA during the COVID-19 pandemic (Student life..., 2020). According to the aforementioned research, health difficulties due to the pandemic were experienced by almost $13 \%$ of respondents (particularly mental health problems resulting from lockdown), while more than $80 \%$ of students declared no health issues. Among students declaring health problems, mental health problems were dominant $(12.9 \%)$, followed by other health issues (4.6\%), chronic illness (3.1\%), and physical disabilities (1.8\%). Similar results were also observed in a survey by P. Długosz (2020a, 2020b) conducted on a population of students in Kraków during the first and second wave of the pandemic. The surveys showed the dominance of psychological problems and ailments over somatic symptoms, with prevalence of symptoms such as: vertigo, stomach ache, or sleeplessness (Długosz, 2000a). As a result of the second wave of the pandemic, more frequent headaches, stomach aches, vertigo, and sleep problems were observed, declared by as many as $60 \%$ of all surveyed students (Długosz, 2020b). Similar results were also observed among students and employees from one of the universities in Spain (Odriozola-González et al., 2020) and Bangladeshi home-quarantined students (Khan et al., 2020). Study results concerning students in Israel, Russia, and Belarus show that COVID-19 linked to their depression (41.0\%), exhaustion (29.9\%), loneliness (47.5\%), nervousness (40.4\%), and anger (31.1\%). This study is one more evidence that pandemic consequences may be linked to health, mental health, education, debt, and job loss concerns (Isralowitz et al., 2020). Gender gap in COVID-19 response reveals that females have a significantly higher level of fear than males (Reznik et al., 2020; Isralowitz et al., 2020). According to our research, health self-assessment, particularly in categories "very good" and "good", proved to decrease by as much as $12 \mathrm{pp}$. During the pandemic, primarily psychosomatic symptoms occurred or intensified, including anxiety, depression, irritability, general indisposition, and others. Along with the above, the pandemic had no considerable effect on life orientations considered in the analysis of life satisfaction. Additional research is needed to study the impact of COVID-19 effects over time and locations. Such information may help guide effective support to students in resembling crisis, and promote development of well-being centres at universities with special attention to mental health support services.

Editors' note:

Unless otherwise stated, the sources of tables and figures are the authors', on the basis of their own research. 


\section{References}

Aucejo, E.M., French, J., Araya, M.P.U., Zafar, B. (2020). The impact of COVID-19 on student experiences and expectations: Evidence from survey. Journal of Public Economics, 191, 104271. https://doi.org/10.1016/j.jpubeco.2020.104271

Bącik, M., Gawarkiewicz, P., Siewicz, K. (2010). Aktywność zawodowa studentów jako przykład pozaakademickiej działalności młodych ludzi. Przeglad Pedagogiczny, 1: 82-92.

Combining studies and paid jobs: Thematic review. (2018). Eurostudent.eu. https://www.eurostudent.eu/download_files/documents/TR_paid_jobs.pdf

Diagnoza Społeczna (2013). Warunki i jakość życia Polaków. Warszawa: Rada Monitoringu Społecznego.

Długosz, P. (2020a). Krakow students in the situation of the coronavirus (COVID-2019) pandemic threat. Kraków: Instytut Filozofii i Socjologii Uniwersytetu Pedagogicznego im. KEN w Krakowie. https://doi.org/10.13140/RG.2.2.20494.72008

Długosz, P. (2020b). Neurotyczne pokolenie koronawirusa? Raport z II fali badań krakowskich studentów. Instytut Filozofii i Socjologii Uniwersytetu Pedagogicznego im. KEN w Krakowie. https://ifis.up.krakow.pl/wp-content/uploads/sites/9/2020/06/Raport-z-II-fali-bada\%C5\%84-student\%C3\%B3w-UP-pdf

EUROSTUDENT VI. (2018). Społeczne i ekonomiczne warunki życia studentów w Polsce na tle innych krajów europejskich. Raport końcowy dla Ministerstwa Nauki i Szkolnictwa Wyższego. Sopot-Warszawa: PBS. https://www.eurostudent.eu/download_files/documents/20181029_EUROSTUDENT_VI_raport_krajowy.pdf

Godlevska, V., Grečaniuk, N. (2008). Pracûûčij student: motivaciâ, problemi. http://conf.vntu.edu.ua/humed/2008/txt/Godlevska.htm

Hauschildt, K., Gwosć, C., Netz, N., Mishra, S. (2015). Social and economic conditions Europe. Sinopsis of indicators. Final report. EUROSTUDENT V 2012-2015, Bielefeld: W. Bertelsmann Verlag.

Hauschildt, K., Vögtle, A.M., Gwosc, Ch. (2018). Social and economic conditions of student life in Europe. EUROSTUDENT VI - 2016-2018. Synopsis of Indicators.

https://www.eurostudent.eu/download_files/documents/EUROSTUDENT_VI_Synopsis_of_Indicators.pdf

Health status of population in Poland in 2014. (2016). Warsaw: Statistics Poland.

https://stat.gov.pl/en/topics/health/health/health-status-of-population-in-poland-in-2014,4,1.html

Ignatovitch, E.S., Kozhuhovskaia, L.S., Salikov, A.E., Sergeeva, Yu.I. (2018). O položenii molodeži $\checkmark$ Respublike Belarus' v 2017 godu. Nacional'nyj doklad, Minsk.

http://nihe.bsu.by/index.php/ru/natsionalnyj-doklad

Isralowitz, R., Khamenka, N., Konstantinov, V., Gritsenko, V., Reznik, A. (2020). Fear, depression, substance misuse and related conditions among multi-national medical students at the peak of the COVID-19. Epidemic, Journal of Loss and Trauma, 26(4), 401-404. https://doi.org/10.1080/15325024.2020.1799521

Khan, A.H., Sultana, S., Hossain, S., Hasan., M.T., Ahmed, H.U., Sikder, M.T. (2020). The impact of COVID-19 pandemic on mental health \& wellbeing among home-quarantined Bangladeshi students: A cross-sectional pilot study. Journal of Affective Disorders, 277, 121-128. https://doi.org/10.1016/j.jad.2020.07.135

Kogut, I., Samochin, I., Kudelia, M., Žeriobkiva, T., Stadnyj, Ye. (2016). Social'no-ekonomičnijportret studentiv: rezul'tati opituvannâ. Cedos.

https://cedos.org.ua/uk/articles/sotsialno-ekonomichnyi-portret-studentiv-rezultaty-opytuvannia

Lebedevich, M. (2019). K voprosu zanâtosti molodeži v Respublike Belarus'. In V.I. Belski (Ed.), Strategiâ razvitiâ èkonomiki Belarusi: vyzovy, instrumenty realizacii i perspektivy: sbornik naučny (pp. 230-234). Vol. 2, Minsk: Pravo i Ekonomika.

Lenart, J. (2014). Student i praca. Historia i współczesność. Przeglad Pedagogiczny, 2, 117-129.

Libanova, E., Cymbal, A., Lisogor, L., Marchenko, I., larosh, O. (2014). Labour market transitions of young women and men in Ukraine. Work 4 Youth Publication Series, 41. http://www.un.org.ua/images/documents/4521/wcms_519747.pdf 
Marozau, R., Apanasovich, V. (2016). Global University Entrepreneurial Spirit Students' Survey National Report Republic of Belarus 2016. Minsk, National Report. Republic of Belarus.

http://www.guesssurvey.org/resources/nat_2016/GUESSS_Report_2016_Belarus.pdf

Obučenie $v$ period pandemii: social'nyj golod $i$ strahi studentov. (2020). https://www.ttsu.ru/about_the_university/news/detail.php?ID=277991

Odriozola-González, P., Planchuelo-Gómez, Á., Irurtia, M.J., de Luis-García, R. (2020). Psychological effects of the COVID-19 outbreak and lockdown among students and workers of a Spanish University. Psychiatry Research, 290. https://doi.org/10.1016/j.psychres.2020.113108

Orr, D., Gwosc, C., Netz, N. (2011). Social and economic conditions of student life Europe. Sinopsis of indicators. Final report. EUROSTUDENT IV 2008-2011, Bielefeld: W. Bertelsmann Verlag.

Ostoj, I. (2016). Motywy podejmowania pracy przez studentów studiów stacjonarnych - wyniki badań. Studia i Prace Wydziału Nauk Ekonomicznych i Zarządzania, 44(1), 231-241.

Parchomiuk, M., Zubrzycka-Maciag, T. (2017). Pracujący studenci. Wybrane korelaty konfliktu i wzbogacenia. Forum Oświatowe, 29(1), 149-166.

PARP. (2019). Rynek pracy, edukacja, kompetencje. Aktualne trendy i wyniki badań. Warszawa: System Rad ds. Kompetencji.

Pew Research Center. (2020). Survey of U.S. adults conducted March 19-24, 2020. https://www.pewresearch.org/fact-tank/2020/03/30/people-financially-affected-by-covid-19-outbreakare-experiencing-more-psychological-distress-than-others/

Piróg, D. (2017). Dokonywanie wyboru usługi edukacyjnej na poziomie wyższym - ujęcie teoretyczne. Prace Komisji Geografii Przemysłu Polskiego Towarzystwa Geograficznego, 31(3), $204-219$. https://doi.org/10.24917/20801653.313.13

Portfel studenta. (2019). Raport ZBP. https://zbp.pl/getmedia/db30e431-257b-4b47-9942-e8164e844966/PortfelStudenta2019

Reznik, A., Gritsenko, V., Konstantinov, V., Khamenka, N., Isralowitz, R. (2020). COVID-19 fear in Eastern Europe: Validation of the fear of COVID-19 scale. International Journal Mental Health Addiction. https://doi.org/10.1007/s11469-020-00283-3

Sokolova, A. (2019). Modern students in job search: Why and how they find it. Visnyk V. N. Karazin Kharkiv National University. Series "Sociological studies of contemporary society: methodology, theory, methods", 1053, 178-180. https://periodicals.karazin.ua/ssms/article/view/13799

Student life in the EHEA during the COVID-19 pandemic. (2020). http://www.ehea.info/Upload/BFUG_HR_UA_71_8_1_Survey_results.pdf

SW Research. (2017). Czego się obawiamy, a na co liczymy. Młodzi Polacy w pierwszej pracy: Raport badawczy: Student w pracy 2017.

https://www.programkariera.pl/wp-content/uploads/2019/03/Raport-Student-w-Pracy-2017.pdf

SW Research. (2019). Student w pracy: Raport badawczy. Marzec 2019. Polska Rada Biznesu. https://www.programkariera.pl/wp-content/uploads/2019/04/Raport-Student-w-Pracy-2019-wyniki-pdf

Szlendak, A., Lemska, M. (2010). Socjologiczna analiza wybranych problemów wśród studentów Wydziału Nauk o Zdrowiu związanych z podjęciem edukacji poza miejscem dotychczasowego zamieszkania. Annales Academiae Medicae Gedanensis, 40, 101-108.

Vankevich, A., Korabava, A. (2019). Empirical research of youth employment and unemployment in Belarus (regional aspect). Vestnik of Vitebsk State Technological University, 2(37), 115-129. 